\title{
A Coy Dauphin
}

\section{ERNEST THESIGER}

From Ernest Thesiger, Practically True (London: Heinemann, 1927) pp. 141-2. Ernest Thesiger (1879-1961), actor, recalls here his flirtatious response to Shaw's inviting him to play the Dauphin in the 1924 production of Saint Joan, a role in which he was brilliantly successful. Thesiger subsequently played a number of important roles in later plays of Shaw.

At last he himself asked me to sit next to him, and said that he had hoped that I would have acted in Saint Joan. 'I have never really wanted to act in any of your plays,' I said. 'I have always thought that a Shaw play could be best performed by several gramophones with very loud speakers.' 'That is one of the reasons why I wanted you in my play,' he answered. 'It is of the utmost importance that what I write should be heard, and you, at any rate, are always audible.' 'There are surely enough loud-voiced parrots,' I said, 'without engaging an artist,' and I changed the conversation. There is nothing so exhilarating as being offered what you most want and then flirting with a refusal. Moreover, I knew that not only did I like Bernard Shaw very much better than I had expected to, but that he also liked me.

After lunch, Mrs Shaw came up to me and said that they were both very much disappointed that I was not going to play the Dauphin, but that she quite understood the position. 'But if Mr Shaw really wanted me,' I said, 'there would be no "position". I am quite certain that he has a veto on the casting of his plays, and that he has only to insist upon my being engaged, for the whole thing to be settled.'

That evening a telephone message engaged me to play in Saint Joan.

My part appealed to me enormously, but I was very nervous lest my reading of it should not be in the least what Shaw wanted. So I was considerably alarmed when after the first rehearsal he came up to me in a most solemn manner and with that fascinating brogue of his said:

'There is one thing I want you to do about this part.'

Humbly I said that I would try to do anything he wished, upon which he continued: 'I want you to go home to bed and stay there till the first night. You already know as much about the part as I do.' 